Acta vet. scand. $1960,1,363-382$.

From the Department of Pathology, Royal Veterinary College, Stockholm.

\title{
HEPATIC AND SUBPHRENIC ABSCESSES IN CATTLE WITH RUPTURE INTO VENA CAVA CAUDALIS
}

By

Sven Rubarth.

It is now a quarter of a century since I first encountered in a cow a liver abscess which had broken through into Vena cava caudalis. Since the publication of the eleven first cases (Rubarth 1942 ) our experience of this lesion has greatly increased and it is now perhaps in its place to describe the material collected in the intervening years. We are dealing here with a cattle lesion which is of equal interest to the practising veterinarian and the pathologist, not least because it frequently leads to sudden and quite unexpected death. Furthermore, this lesion, so common in our experience, has attracted surprisingly little attention in the veterinary literature.

Liver abscesses are seen more often in cattle than in other domestic animals. In this species they can occur as solitary lesions or as a manifestation of a purulent hepatitis. Multiple abscesses, at least when not too numerous or extensive, can be encountered incidentally in the livers of slaughter animals which had apparently never shown any clinical signs. Both the acute and chronic form, however, can produce clinical signs severe enough to warrant slaughter of the affected animal. Solitary abscesses, seen so often in older cattle sent to slaughter, are generally clinically silent. On occasion, however, solitary abscesses can give rise to servere and often fatal clinical disturbances of the type which I shall discuss in this paper.

The material upon which this description is based is taken from the records of this department. Among the 1279 mature cattle autopsied here during the last twenty-five years, there were 
fifty-three with liver or suphrenic abscesses, two with thoracic abscesses, and one with a retroperitoneal abscess, all of which had broken into the caudal vena cava (Fig. 1) and in one instance, into one of the hepatic veins (Fig. 2). I am most concerned here with the pathological and bacterialogical findings ${ }^{1}$ ) and with the patho-physiology of the disease but will also briefly deal with the clinical observations and other available information on the animals.

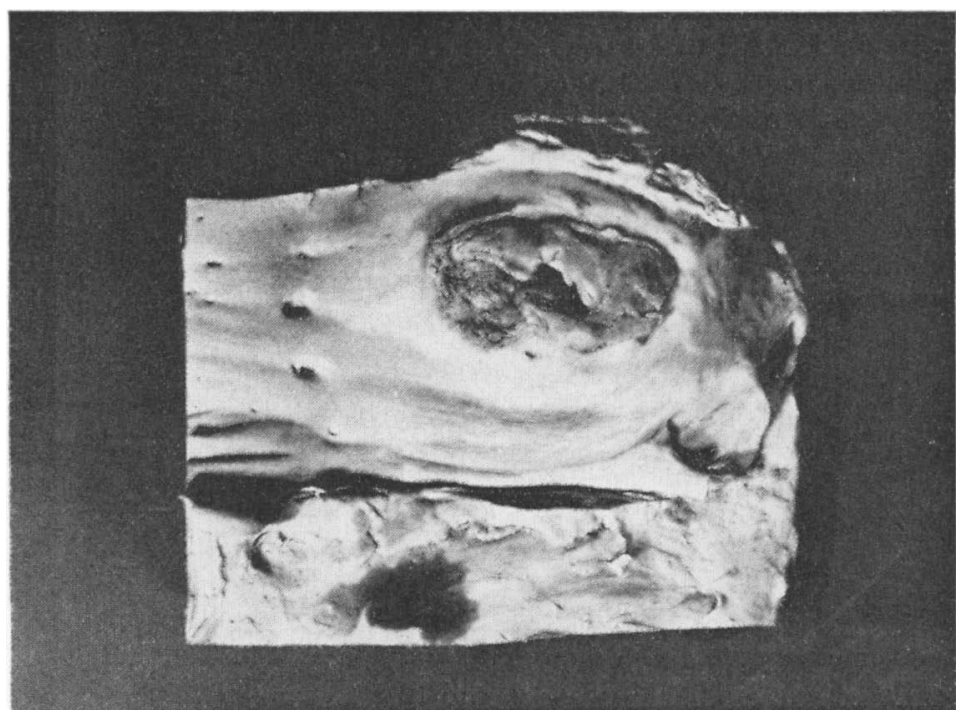

F i g. 1: Erosion of the wall of the caudal vena cava by an abscess with formation of a mural thrombus about the opening.

In no instance was there opportunity to consult a veterinarian before death. Fifty-one of the fifty-six animals were unexpectedly found dead in the stable or at pasture without anything unusual having been noticed. Two of these animals, in fact, died during the "few minutes" the farmer happened to be absent. Some of the animals were found with a pool of blood under the nose or with red-coloured frothy oedema fluid around the nostrils. None of the farmers has mentioned finding traces on the ground or in the bedding which would suggest that the animal went death throes. Two bulls and a cow died immediately after service.

1) The bacteriological examinations were carried out at the Department of Bacteriology (Head: Prof. H. Hedström). 


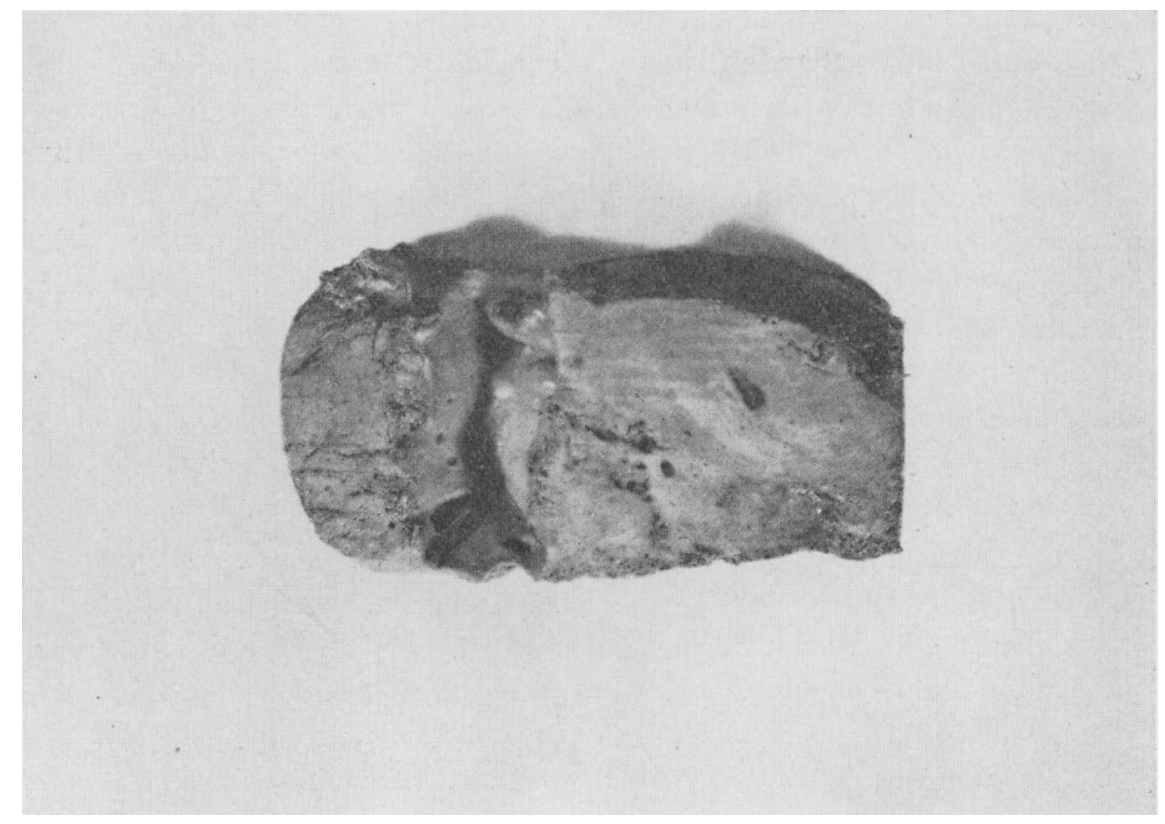

F i g. 2: Abscess perforation at the point where an hepatic vein emties into the caudal vena cava.

Only five animals showed any clinical signs at all. Three cattle appeared to suffocate and frothy oedema fluid ran from the nostrils. One cow began to pant, stood with her head pressed against the manger, developed violent diarrhoea, and again, frothy and bloody oedema fluid ran from the nostrils. The fifth suddenly began to champ froth, then fell forwards and died. A very rapid fatal course, then, is characteristic for these cases.

It can be mentioned that during the period included in this study we have received about 20 specimens taken from animals slaughtered for salvage, containing abscesses with erosion and break through into the caudal vena cava. The clinical course for these animals had been more prolonged and the signs observed were depression, fever, and metastatic pneumonia. That the liver abscess was the cause of the disturbances was not established clinically for any of these animals.

As mentioned above, it is remarkable that deaths through rupture of these abscesses into this large vein have largely escaped notice in the literature. It is possible that the occurrence 
and incidence of liver abscesses varies between regions and countries and that in Sweden they are especially common.

The possibility that the lesions-if the autopsy appearance is unknown - may be overlooked can not be ignored and could at least explain partially the paucity of reports. Once recognised, the stigmata are so characteristic that further cases and the real cause of death will be readily detected. Sudden and unexpected deaths among cattle can arouse suspicions of anthrax and the cause of such deaths would not be further investigated. I shall return to this point later. An important prerequisite for establishing the correct diagnosis is the use of an exact technique in evisceration. This technique will be described below.

The autopsy appearance in peracute cases is generally characterised by the following changes. An almost invariable observation and one which can be made at an early stage during autopsy is the extremely well-coagulated and nearly black blood ("currant-jelly" clot). Clots of this appearance are regularly found in the heart and the large veins and in many instances in the smaller branches as well. This observation arouses the suspicion of bacterial activity and raises the possibility of a purulent caval erosion. With this in mind one can continue evisceration in a suitable manner. After removal of the omentum, spleen, forestomachs, abomasum, and intestines from the abdomen, the caudal vena cava is opened along the edge of the liver to the diaphragm. When the generally entirely black clot has been picked out of the vessel, the internal surfaces of the vein can be inspected for the changes seen in the type of erosion concerned here. The vein should bee examined as far forwards as possible, even past the diaphragm, in order to detect possible abscesses lying outside the liver (subphrenic or thoracic) which can have broken through. If this inspection is neglected, cutting the liver free from the diaphragm and removal of the organ will damage subphrenic abscesses at least and their vascular relationships, and greatly increase the difficulties of correct interpretation.

Occasionally the abscess produces an inward bulging of the vein wall and this prominence is covered by a fibrinous endophlebitis about an often fine perforation. If the perforation is large, there will instead be a local outward bulging over the wholly or nearly empty abscess cavity. The blood clot which covers the abscess perforation often has a greyish-brown sticky deposit on its surface with superficial lysis. Bacteria from the abscess con- 
tents thrive in the environment afforded by the clot and at the same time produce a degree of liquefaction. On a few occasions we have seen how a mural thrombus has formed over the site of impending and subsequently established perforation and has become centrally liquefied and ruptured to offer free passage for the abscess contents out into the blood (Fig. 3).

It is quite natural that of the other organs it is the lungs which show the most obvious changes. They are often, and some-

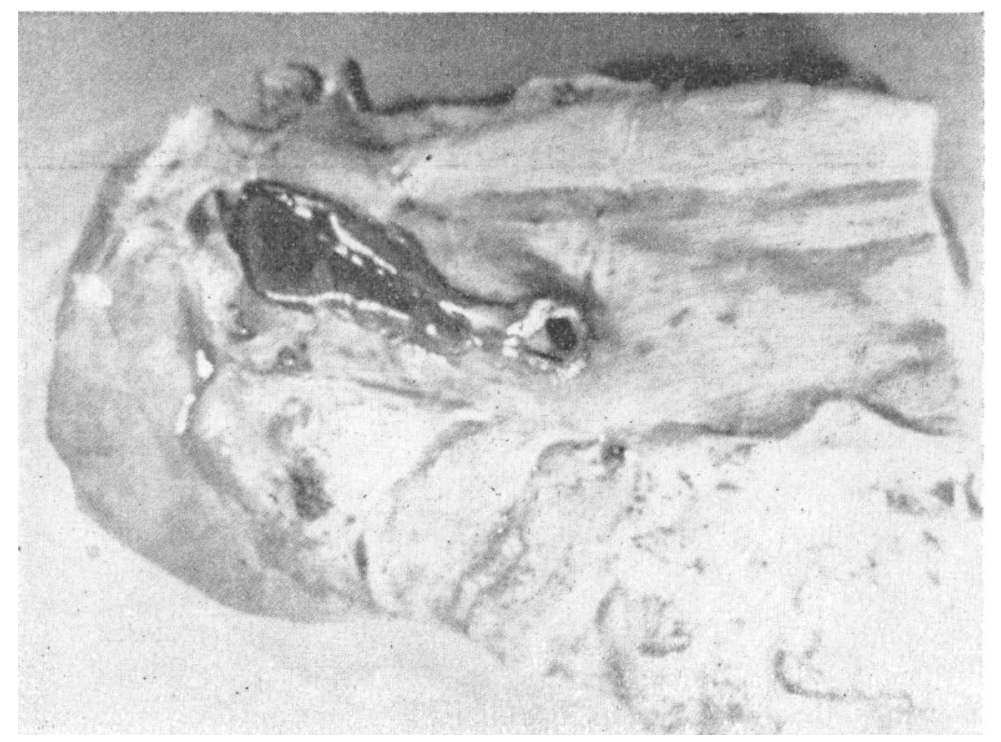

F i g. 3: Mural thrombus in the caudal vena cava. The right portion of the thrombus has been incised (circular opening) to demonstrate erosion of the vein by the abscess. $(0.915 / 50)$.

times to an extreme degree, expanded by alveolar and often interstitial emphysema as well. Hyperaemia and oedema, as would be expected from the clinical description, are also generally observed. Large numbers of small haemorrhages are apparent on the pleural and the cut surfaces and occasionally even large septic infarcts. On section, the haemorrhages have a dull and dry surface, presumably a reflection of the extreme rapidity of coagulation. The bronchi and sometimes the upper respiratory passages as well generally contain frothy oedema fluid which now and then is blood-tinged. The mucous membranes of the respiratory passages, from the nose to the finer branches of the bronchi but 
sometimes concentrated within certain regions, contain numerous small haemorrhages. These haemorrhages are generally petechial but especially is the trachea they can be confluent. The retromucosal space usually contains a bloody oedema fluid. Subepiand subendocardial haemorrhages, especially on the left side of the heart, are seen in various numbers and sizes. The serous cavities often contain transudate with, upon occasion, subserous haemorrhages. Haemorrhagic oedema can be found both interand intramuscularly. The spleen is usually swollen, hyperaemic and the dark red pulp soft and bulging. Hyperaemia, oedema, and haemorrhages can be found in the lymph nodes.

A few cases will be cited as examples.

\section{Case I.}

History: One afternoon this cow refused to eat and suddenly developed dyspnoea. Her condition deteriorated during the evening but in the middle of the night she appeared somewhat better. A few hours later she was found dead.

Autopsy (0. 1194/58): A nine-year-old cow in a moderately good state of nutrition. Cadaverous changes were slight. Subcutaneously and ventrally over the neck, ventrally on the left side in the neck muscles, and in the adductor muscles were found a moderate degree of oedema and haemorrhages up to $10 \mathrm{~cm}$ in diameter. The blood, especially in the heart and large veins, was well coagulated as a "currant-jelly" clot. Upon opening the caudal vena cava and removing the clotted blood, a slight elevation was apparent immediately posterior to the level of the diaphragm. At this highest point, the elevation was covered with a reddish thrombus about $2 \mathrm{~cm}$ in diameter. A perforation $2 \mathrm{~mm}$ in diameter led from the caudal portion of this thrombus through the caval wall and opened into a liver abscess with a diameter of about $5 \mathrm{~cm}$ and surrounded by a dense whitish connective tissue capsule about $1 \mathrm{~cm}$ thick. The portion of the capsule abutting upon the canal wall gradually thinned out.towards the point of perforation. The abscess contents were greyish white, creamy, and foul-smelling. The lungs were greatly expanded by alveolar emphysema and, over some areas, by an interstitial emphysema separating lobules by several centimetres. The emphysema made the lungs quite resilient upon palpation. The combination of scarlet, greyish-red, and emphysematous lobuli with the varying degrees of oedema in different areas gave the lungs a patchy, almost marbled appearance. Numerous petechiae and ecchymoses were found in the mucous membrane and submucosa of the larynx and upper threequarters of the trachea. In the retromucosal space these haemorrhages were confluent over large fields. The mucous membrane of the distal fourth of the trachea and of the bronchi was hyperaemic.

Each pleural cavity contained about a litre of wine-coloured transudate. The costal and diaphragmatic pleurae were studded with petechiae and ecchymoses, most numerous towards the vertebral 
column and along the costal-phrenic reflection. The right diaphragmatic lobe, immediately laterally and ventrally to the foramen venae cavae and opposite the liver abscess, was fixed to the diaphragm by fibrino-fibrous adhesions over an area $10 \mathrm{~cm}$ in diameter. Similar adhesions were found between the diaphragm and the liver in the region of the abscess. There was also a fibrous adhesion between the ventral reticulum and the diaphragm.

Lateral to the left kidney and along the left shaft of the ilium there were numerous subperitoneal haemorrhages and a great accumulation of oedema fluid. Subserous petechiae and ecchymoses were also present along the left side of the anterior cranial chamber of the rumen and over the abomasum. Numerous small haemorrhages and a pronounced oedema were found at the root of the mesentery.

Numerous widespread and in some places confluent subepicardial haemorrhages were seen over both atria, and subendocardial haemorrhages were prominent dorsally in the left ventricle. The papillary muscles contained several elongated haemorrhages.

Microscopically, in the myocardium there is in addition to the haemorrhages, fragmentation of the myocardial fibres. Of the numerous haemorrhages in the lungs some have begun to assume the character of haemorrhagic infarcts. In the smaller branches of the pulmonary arteries, but especially in the capillaries, there are basophilic, finely granular emboli composed of bacteria and exudate. (Fig. 4).

Bacteriological examination of the abscess contents and lungs demonstrated Corynebacterium pyogenes animalis. Abundant growth of coliform bacteria was also obtained here and from a precapsular lymph node and the spleen as well.

Autopsy diagnosis: Liver abscess with rupture into $V$. cava caudalis.

Case II.

History: This cow died suddenly in the evening. Nothing abnormal had been noticed when she was seen in the afternoon.

Autopsy (0. 277/58) : A five-year-old cow, in advanced pregnancy, weight $570 \mathrm{~kg}$. The nutritional state was good and the cadaverous changes were slight. Subcutaneously, and inter- and intramusculary over the thorax and lower neck were found numerous haemorrhages from petechiae to those measuring up to $10 \mathrm{~cm}$ in diameter. Haemorrhages of the same type were present to a much lesser extent over some other parts of the body. A number of haemorrhages were also present in the lingual muscles. Over an area about $20 \mathrm{~cm}$ in diameter the liver was firmly fixed to the diaphragm by fibrous adhesions. These adhesions covered an abscess. The organ as a whole was moderately enlarged with blunt edges, the parenchyma was light in colour and very soft. Immediately under the point of exit of the caudal vena cava there was an abscess the size of an orange with a fibrous capsule $1 \mathrm{~cm}$ thick. This abscess bulged into the caudal vena cava to reduce its lumen by about half. 


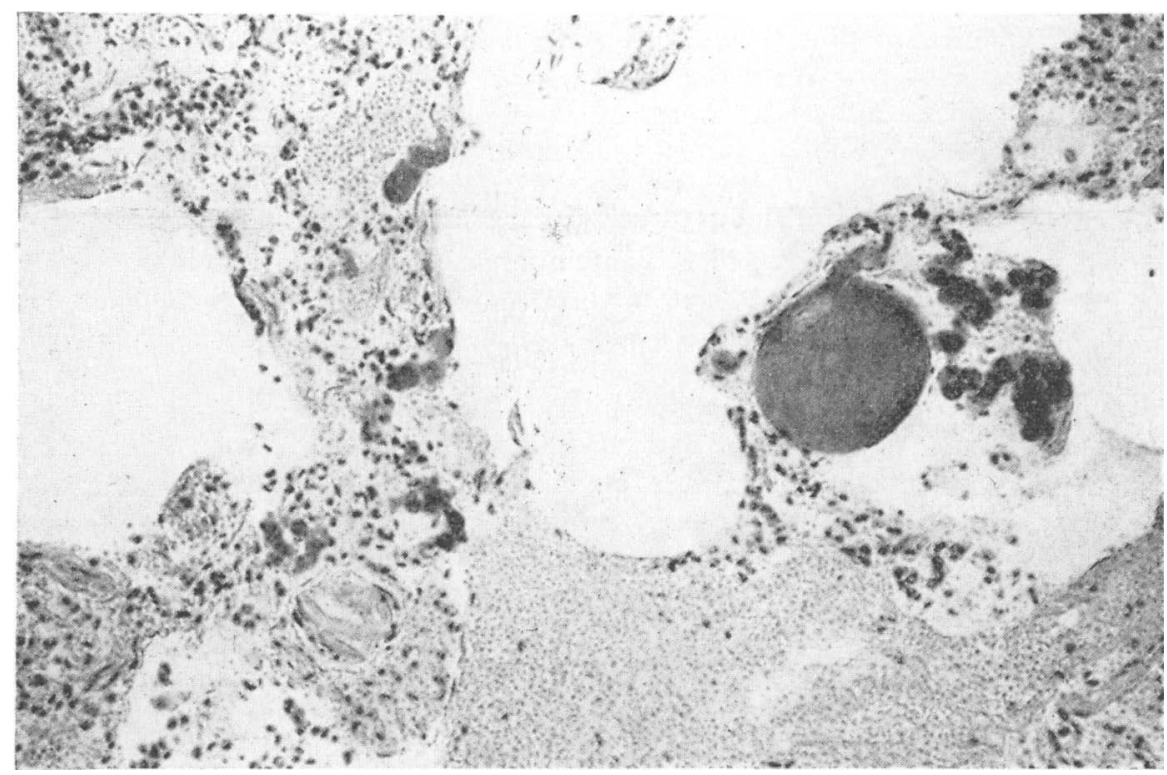

Fig. 4: Bacterial emboli in a pulmonary artery and in the capillaries. Haemorrhages and emphysema. (0.1194/58).

Macroscopically, the wall of the explored portion of the abscess was whole but leaf-thin. The caval intima over the abscess was reddened, studded with small haemorrhages, and covered with a thin thrombus. In addition to the large abscess, the liver contained numerous smaller abscesses ranging in size from $2 \mathrm{~cm}$ to $5 \mathrm{~cm}$ in diameter, some containing thick yellowish-green pus and others of a firmer, more homogeneous consistency with grey-orange liquefield centres. The lungs were voluminous, hyperaemic and moderately oedematous with a rubbery consistency. The individual lobuli were evident on the cut surface with their alternating light and dark colour and the interstitial oedema. Numerous petechiae were scattered throughout the parenchyma. The trachea and bronchi were filled with cream-coloured frothy oedema fluid and their mucous membranes thickly studded with small haemorrhages and a few larger ones. Ecchymotic haemorrhages were also seen in the laryngeal mucosa. Extensive inter- and intramuscular haemorrhages occupied the retropharyngeal tissues. The cervical portion of the thymus and the oesophageal submucosa contained numerous small haemorrhages. All the body lymph nodes were quite hyperaemic and oedematous. The spleen was swollen and the very soft pulp dark in colour. Both the udder and the vagina were distinctly hyperaemic and contained many small haemorrhages.

Microscopically there is moderate, diffuse, fine-droplet fatty change in the liver cells, and in the lungs, oedema, emphysema, and 


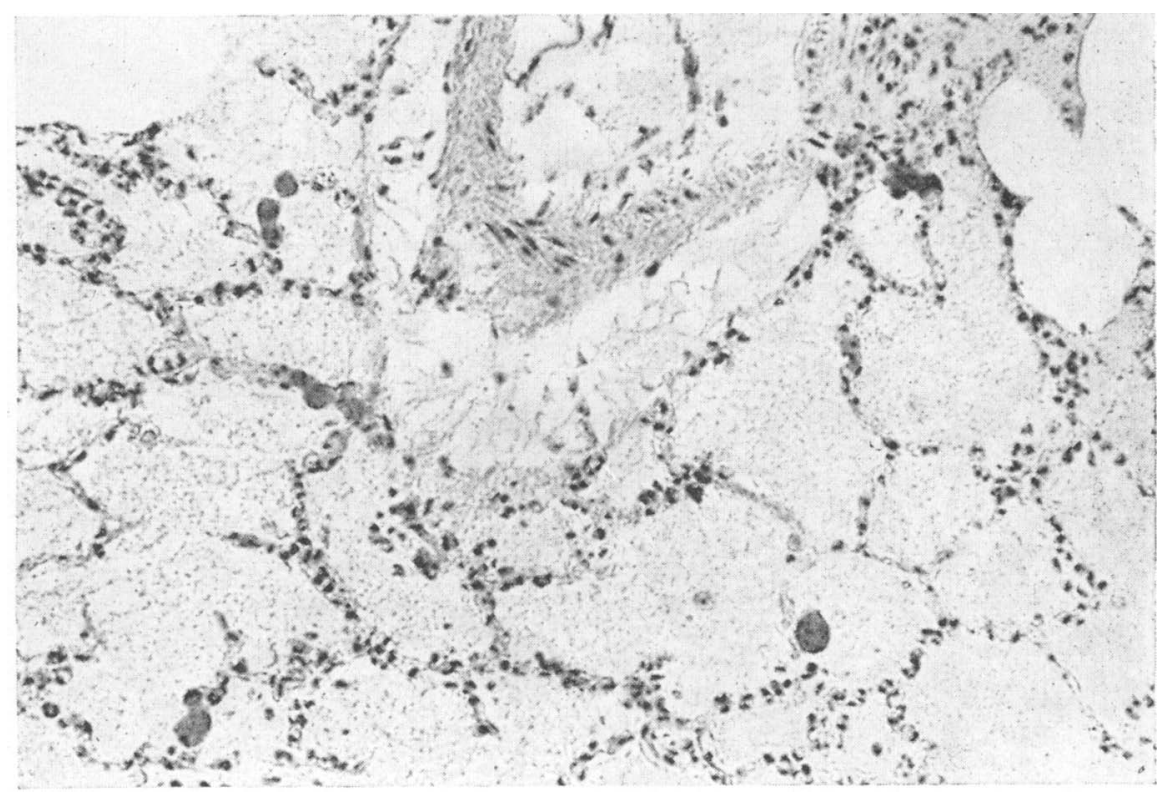

F i g. 5: Multiple bacterial colonies in the capillaries and severe oedema. (0.277/58).

haemorrhages. The oedema is largely alveolar and irregularly interstitial with here and there abundant leucocytes with a large proportion of eosinophils. In many capillaries and especially in those lying peripherally there are amorphous emboli staining grey with haemalum-eosin (Fig. 5) and sometimes with a distinct basophilic stippling (bacteria). Some of the larger branches of the pulmonary artery contain tightly-packed and partially destroyed leucocytes.

When examined bacteriologically, the liver abscesses, spleen, and prescapular and popliteal lymph nodes gave an abundant growth of Corynebacterium pyogenes animalis.

Autopsy diagnosis: Multiple liver abscesses with rupture of an abscess into V. cava caudalis.

As in case II we have occasionally been unable to demonstrate a macroscopic rupture of the part of the abscess wall formed by the overlying vena cava. For several reasons there can be little doubt that such cases rightly belong in this material. There is the fact of sudden and unexpected death with autopsy findings similar to those seen in cases with indisputable perforations, the reaction and haemorrhages in the venous intima over the site of threatened rupture and bacteriological recovery of the same organism from the abscess and the lungs. Furthermore, there is 
the observation of numerous bacterial emboli in the pulmonary capillaries, and in one case, histologicai evidence of inflammation in the thinnest part of the common abscess and vessel wall.

Rupture of an abscess into one of the larger veins does not necessarily lead to death as rapidly as was the case in the material at my disposal. Clinical signs of varying duration may be manifested, if merely a few exudate masses or exudate containing bacteria of low virulence are discharged into the blood. We have received organ specimens from 30 or 40 animals which had been slaughtered. Examination of such specimens usually shows tromboendophlebitis with metastatic lesions, such as pneumonia or abscesses in the lungs, and sometimes further dissemination to the kidneys with a similar inflammatory reaction. The aetiologic and pathogenetic relationship in the various organs was always confirmed by bacteriological examination.

In two of the animals included in this series we found focal fibrino-necrotic pneumonia and multiple pulmonary abscesses, respectively. Through enquiries it could be ascertained that both these animals had been depressed and had a reduced appetite for a few days before death suddenly occurred, and that the animal with pulmonary abscesses had also coughed. In these instances, bacteria had been released into the blood some time before death and it was this release that led to the pneumonic changes. Such a case will be described in greater detail.

\section{Case III.}

History: The first sign noticed was anorexia. During the next five days the cow was depressed and had little or no appetite. On the afternoon at the fifth day she was found dead in the stable.

Autopsy (0. 87/39): The cow weighed $471 \mathrm{~kg}$ and was in a good state of nutrition. Rigor mortis had commenced and cadaverous changes was insignificant. Haemorrhagic oedema extended subcutaneously and intermuscularly over the right side of the neck. The blood was practically black and was well coagulated. An abscess the size of a fist and filled with yellowish-grey pus was situated between the liver and the omasum. From the abscess a fistula about $1 \mathrm{~cm}$ in diameter led diagonally upwards towards the vena cava and opened into another abscess of about the same size. The wall of the latter abscess bulged into the caudal vena cava. Over the bulge the wall was extremely thin, friable and pierced by a very fine passage from the abscess to the vena cava. The contents of this abscess resembled those of the former. The portion of the cavity adjacent to the vena cava contained firm clumps of necrotic material about 3 or $4 \mathrm{~cm}$ thick. The liver was somewhat enlarged (rel. wt. 3.6 per cent) and showed the stigmata of chronic 
stasis as well as numerous fibrotic foci about $2.5 \mathrm{~mm}$ in diameter. The lungs were voluminous and strongly hyperaemic, oedematous, and emphysematous. Schattered throughout all lobes were pneumonic areas measuring up to $5 \mathrm{~cm}$ in diameter, often with a dry, almost necrotic cut surface. Small emboli were seen in the smaller branches of the pulmonary arteries. The lung parenchyma in the immediate neighbourhood of these emboli was quite hyperaemic. Petechiae and ecchymoses were found in the middle portion of the tracheal mucous membrane. Haemorrhagic oedema occupied the retromucosal space and petechiae were found in groups under the parietal pleura. There were no obvious changes in the kidneys. The abdomen contained 2.5 litres, the thoraxic cavity 1.5 litres, and the pericardial sac $150 \mathrm{ml}$ of reddish transudate.

Microscopically, purulent to necrotic pneumonia can be demonstrated in the foci visible macroscopically. Bacterial emboli occupy many of the smaller vessels and a few such emboli are present in the larger branches as well. In the kidneys there is a very recent embolic glomerulonephritis.

At bacteriological examinations, Corynebacterium pyogenes animalis, staphylococci, and coliform bacteria were isolated from the abscess, from the lungs Corynebacterium pyogenes, staphylococci, and necrosis bacillus, and from the heart blood and spleen, the hay bacillus and a few colonies of $E$. coli.

Autopsy diagnosis: Liver abscess with rupture into the caudal vena cava, embolic pneumonia, and embolic glomerulonephritis.

In this material the abscesses invariably involved the dorsal portion of the liver immediately ventral to the caudal vena cava and were generally situated far to the left towards or adjacent to the foramen venae cavae in the diaphragm. In vessels of these great dimensions complete thrombosis - a process which would prevent escape of the abscess contents into the blood streamseldom occurs.

In one animal $(0.995 / 59)$ the liver abscess had caused the formation of an obliterating thrombus about $15 \mathrm{~cm}$ long and practically completely organised. The thrombus itself contained an abscess about $5 \mathrm{~cm}$ in diameter. The liver abscess extended through the thrombus to its central apex. Over the point of nearrupture at the apex, fresh fribrinous deposits had been laid down. No blood could pass the vena cava at this point because of the complete obstruction. But the thrombus was so situated that patent and uninvolved hepatic veins opened into the vena cava centrally and peripherally to the point of obstruction. The hepatic veins and their branches were greatly dilated and judging from their almost cavernous appearance it seems likely that blood from the caudal portion of the body flowed past the occlu- 
sion through these anastomising vessels. Congestion with oedema was not seen in the posterior portion of the body.

Similar findings were made in liver specimens obtained at normal slaughter, and was interpreted in the same manner. Unequivocal and irrefutable evidence for the correctness of this interpretation is not available; on the other hand in spite of careful search I have been unable to demonstrate any other by-pass past the large occluding thrombus in the vena cava. In some livers obtained from slaughtered cattle, the thrombus lay so far cephalad that no branch of the hepatic veins opened more centrally into the vena cava. The signs of congestion in the liver were so pronounced and of such an age that it must be assumed that the blood has returned to the heart by some extra-hepatic route. Since only the livers were available for examination in these instances, we could not study this point further. In human beings of course, the development of collaterals under these circumstances is well known. A case of this type with a liver abscess but only partial thrombosis of the caudal vena cava has been described by Wyssmann (1912).

Liver abscesses can occur in any of our domestic animals, although the incidence varies. During the past twenty-five years in our department we have observed this lesion most frequently in mature cattle, in 4.35 per cent of the 2,255 autopsies on this species. The corresponding figures for horses are 0,55 per ceni ( 1,948 autopsies), for cats 0.54 per cent (1,494 autopsies), for dogs 0.42 per cent $(11,162$ autopsies), and for pigs 0.30 per cent (2,879 autopsies). A much higher incidence has been recorded from North America among cattle slaughtered normally. During 1950 and 1951 Keith (1955) found liver abscesses in 10.6 per cent of adult cattle, and two years later the incidence had increased to 13.0 per cent. We have only seldom liver abscesses in young cattle, and Keith also mentions that they are rarely present in calves under one year of age. In young and even newborn calves, on the other hand, we have often scen miliary and submiliary abscesses, generally very numerous, caused by streptococci or less commonly by organisms belonging to the family Listeria ( $R \boldsymbol{u}$ barth and Wollarz 1951). In horses, our percentage would be almost doubled, if we included the microscopic abcesses which in this species develop during pyaemia caused by Shigella equirulis, $E$. coli, and streptococci. 
Liver abscesses can be classified according to their pathogenesis as traumatic or metastatic. Traumatic abscesses are generally solitary. In about half the animals included in my series, there were fibrous adhesions between the reticulum and the diaphragm with, in some distances, involvement of the liver as well. Within the firm fibrous adhesions in two animals there were fistulas containing foreign bodies. But in no instance was there conclusive support for a pathogenic relationship between the chronic traumatic peritonitis and the liver abscess. Furthermore, traumatic abscesses are usually situated much more ventrally than are those with which we are concerned here.

Metastatic liver abscesses result from infection spreading with the blood, lymph, peritoneal fluid or along the biliary ducts. The liver lesion is then secondary to a primary lesion or to infection entering through another organ. In traumatic splenitis of cattle, for example, Söderlind (1958) found in 88 per cent of the cases haematogenous metastases in the liver, among other places. From studies of the intestinal canal as the point of entry for infection it appears that even in the absence of evident lesions in the intestinal wall, infectious lesions in, for example, the liver can be secondary and metastatic to origin from the gastro-intestinal tract. It is only upon extremely careful search that lesions which are or could be the point of entry can be demonstrated. Experimental studies with several bacterial species (Arnold and Brody 1928, and Nickel and Gisske 1941, among others) have shown that microorganisms can penetrate the intact intestinal mucous membrane and spread throughout the body, but principally to the liver. Many writers consider that there is an intimate relationship between rumen ulcers and liver abscesses and that the rumen serves as the point of entry (Smith 1933, Jensen et al 1947, $1954 \mathrm{a}, 1954 \mathrm{~b}$, and Keith 1955). A clear point of entry from the rumen was not evident in my material and a possible explanation for this divergence in results is the particular bacterial species involved; the above mentioned authours could demonstrate $F$. necrophorus. Even so, it is likely that the infectious agent in my cases of liver abscess entered from the gastrointestinal tract. Since no conclusive evidence for this can be presented, these abscesses can be most adequately classified as cryptogenic.

In the material presented here there were 14 examples of subphrenic abscesses. These varied in size and were situated be- 
tween the liver and the diaphragm, generally adjacent and ventral to the foramen venae cavae. Removal of the liver by the usual autopsy technique will result in an incision through the abscess and damage of the vessel wall at the point of possible erosion. Incision in and internal inspection of the vena cava as the first step will avoid this. The term subphrenic denotes the comparable lesions in human beings and an explanation of their pathogenesis must necessarily be based-as far as one can go-upon experience of the lesion gained in human beings. In his monograph on subphrenic abscesses, Harley (1935) described 188 examples. Of these, 18 were primary and 170 secondary, mainly to perforating peptic ulcers, appendicitis, and abdominal operations. Only 2 were associated with liver abscesses. Others (Ochsner and DeBakey 1938, Faxon 1940, Clagett and Tinney 1944, Thorek 1947, and Spellberg 1954) consider appendicitis and lesions of the stomach and duodenum and of the liver and gall-bladder to be the commonest cause of subphrenic abscesses. Of Harley's 188 cases, the pathogenesis of 154 could be associated with intraabdominal infections or surgical manipulations. A haemotogenous origin was likely in only 4 instances. Through experiments on dogs (Overholt 1931 and Overholt and Donchess 1935), it has been demonstrated that the pressure in the suprahepatic region is lower than in the rest of the abdominal cavity when the animal is standing on all four legs, and that this subphrenic pressure varies with the respiratory phases, being lower during inspiration and higher during expiration. Regardless of the position of the abdomen, horizontal or vertical, there are effective forces which can transport infected peritoneal fluid to the subphrenic region.

Signs of peptic ulceration in the abomasum or duodenum or of cholangitis were not observed in my cases of subphrenic abscess. Nor were there peritoneal adhesions as sequelae to such lesions. In 3 of the 14 animals with subphrenic abscesses there were fibrous adhesions between the recticulum and diaphragm but no continuity between these and the abscesses. It is most probable, however, that there was a pathogenetic relationship between the adhesion and the subphrenic abscesses. In no instance there was a connection by scar tissue or fistulas between the liver or subphrenic abscess and the traumatic peritonitis seen in many animals.

There is no fully adequate explanation for the pathogenesis 
of the two thoracic and the retroperitoneal perinephritic abscesses.

The common microscopical features of the lungs were oedema, haemorrhages, and emboli of varying size, and in one animal, even of varying nature. Usually these were capillary emboli consisting mainly of bacteria, but in some small groups of lobuli the capillaires were stuffed with finely granular masses staining a dusty grey or bluish grey with haemalum-eosin. As the only tissue reaction the blood vessels in the vicinity were distended with blood or small haemorrhages. Other capillaries, which were the seat of emboli, were surrounded by a great number of leucocytes, predominantly eosinophils. There was the impression that these bacterial emboli are most numerous at the periphery of the lobuli, close to the interlobular septa and under the pleura. The oedema, which with the haemorrhages, dominated the appearance of the lungs, was especially evident in the interlobular and subpleural interstitium.

On occasion, emboli from the somewhat granular abscess contents or from the thrombus in the caudal vena cava were encountered. These emboli were larger, occupied wider vessels, and consisted of a necrotic mass or fibrin enclosing varying numbers of leucocytes. The bacterial content was not so evident in these emboli as in the capillary emboli. In the lung parenchyma adjacent to these large emboli there was often fibrinous or purulen $\boldsymbol{t}$ inflammation with a surprisingly great number of eosinophils. The inflammatory reaction in the lungs appeared more evident in cases in which larger and presumably fewer emboli were lodged than when and where bacterial emboli occurred.

Of the other organ which were examined microscopically, bacterial emboli in capillaries were seen in the glomeruli and interstitium of the kidneys, and in the myocardium, liver, and uterus. 'These emboli were not associated with an inflammatory reaction. In one animal waxy degeneration, in addition to oedema, could be seen in the skeletal musculature.

A bacteriological examination of the abscesses was carried out in 54 cases. Corynebacterium pyogenes animalis alone was isolated from 30 abscesses, streptococci alone from 5, mixed streptococci and Corynebacterium pyogenes animalis from 5. $F$. necrophorus alone from 5, and the latter organism together with streptococci from 3 abscesses. Of the remaining 4 abscesses from which a mixed flora was obtained, all contained $F$. ne- 
crophorus and 3 of them Corynebacterium pyogenes animalis as well. Three abscesses were bacteriologically sterile. Hülphers (1914) examined 100 liver abscesses in cattle and found that $\mathrm{Co}$ rynebacterium pyogenes animalis, streptococci, and the necrobacillus predominated bacteriologically in that order, an observation which agrees with the results presented here. From liver abscesses in calves, Schumann (1908) recovered streptococci, staphylococci and E. coli. Joest (1921) records the presence of Corynebacterium pyogenes animalis, streptococci, and staphylococci in enterogenous liver abscesses in mature cattle. Of 100 liver abscesses, Newsom (1938) found 96 to contain F. necrophorus, in some instances together with cocci and Corynebacterium pyogenes animalis. He found only one example of pure pyogenes infection.

In some countries $F$. necrophorus seems to dominate as a cause of liver abscesses in cattle (Newsom 1938, Yamamóto 1938, Cooper, Elliot and Woodman 1942, Smith 1944, Madin 1949, Robinson, Jasper and Guilbert 1951 and Keith 1955). Several investigators (Smith 1944, Jensen et al. 1947, 1954, Madin 1949 and Keith 1955) have found a close relationship between rumen ulcers and liver abscesses of this aetiology. There is no recent statistical and aetiological survey of liver abscesses in the cattle of this country. The results of the cattle autopsies and examination of the organs submitted to this depariment, however, suggest that Corynebacterium pyogenes animals is the most important organism involved in this liver lesion. In the material at my disposal there is no record of a rumen ulcer associated with necrosis bacillus abscesses in the liver. In subphrenic abscesses of human beings, the organisms found are Staphylococcus aureus, streptococci and E. coli, often in a mixed flora (Ochsner and DeBakey 1938 and Harley 1955). In bacterial liver abscesses in man Spellberg (1954) lists E. coli, streptococci, and staphylococci as the most common organisms.

I have been able to find only three previous descriptions of bovine liver abscesses of the type described here with erosion of the caudal vena cava and discharge of the abscess contents into the blood stream, namely those by Franck (1890), Reimers (1904), and my own previous paper (1942). The reasons why this, in our experience, relatively common cause of death has largely escaped attention are either that abscesses of this type are unusual in other countries or that cases of sudden death have 
aroused suspicion of anthrax, and according to regulations have not been autopsied and the cause of death left in doubt. Judging from our experience in this department and the results of examinations for anthrax carried out on blood samples submitted to the State Veterinary Medical Institute, Stockholm, anthrax seldom occurs in cattle in this country. During the 25 years covered by this survey we have received for autopsy 713 mature cattle which died suddenly and unexpectedly. The most common cause of death among these animals was tympanism followed by casis with sepsis of various aetiology and clostridiosis. In the fourth place are the purulent vascular erosions described here. Only about 5 per cent of the blood samples from non-autopsied animals submitted to the State Veterinary Medical Institute for anthrax examination were positive. It is quite possible, and indeed probable, that many of the negative samples taken from animals which in accordance with regulations were not autopsied, actually originated from animals dying of an erosive abscess in the liver.

The actual cause of death following rupture of an abscess into the caudal vena cava can undoubtedly vary from case to case. Just as a direct cardiac failure as the result of interruption of circulation through the coronary arteries, possibly in combination with an extreme load on the right heart, has been postulated to arise from large, occluding pulmonary emboli, it is possible that a shower of smaller emboli in the smaller vessels of the lungs would have the same effect. These larger lung emboli are, however, accompanied by a congestive oedema in the alveoli of the lungs as well as in other places. 'That death in such instances could be the result of brain damage has also been suggested. Clinical and experimental observations on human beings (Crafoord 1939) have shown that anaemia of the brain and the tissue damage arising from this could be the cause of death. 'There is yet another possibility; sensitisation to the abscess contents could be established in these animals and when the contents are discharged into the blood-stream an allergic shock could be precipitated. The very rapid death, the widespread oedema and haemorrhages, and the local eosinophilia in the lungs, in my opinion strongly suggest that this is the correct explanation. 


\section{REFERENCES}

1. Arnold, L. and Brody, L.: Proc. Soc. exp. Biol, 1928, 25, 247.

2. Clagett, O. T. and Tinney, W. S.: Amer. J. Surg. 1944, 66, 189

3. Cooper, K. E. Elliot, E. M. L. and Woodman, D.: J. Path. Bact. $1942,54,529$.

4. Crafoord, C.: Nord. med. 1939, 2, 1043.

5. Faxon, H. H.: New England J. Med. 1940, 222, 289.

6. Franck: Bad. thierärztl. Mittheilg. 1890, 76. Ref. Jahresbericht $1890,107$.

7. Harley, H. R. S.: Subphrenic Abscess, Blackwell Scientific Publications. Oxford 1955.

8. Hülphers, G.: Slakthus och saluhallsdirektörens berättelse för år 1914.

9. Jensen, R.: Frey, P. R., Cross, F. and Connell, W. E.: J. Amer. Vet. Med. Ass. 1947, 110, 256.

10. Jensen, R.: Flint, J. C. and Grisser, L. A.: Amer. J. Vet. Res. 1954, $15,5$.

11. Jensen, R., Deane, H. M., Cooper, L. J. and Miller, V. A.: Amer. J. Vet. Res. 1954, 15, 202.

12. Joest, E.: Handbuch der speziellen pathologischen Anatomie. $1921,2,128$.

13. Keith, T. M.: N. Amer. Vet. 1955, 36, 911.

14. Madin, S. H.: Vet. Med. 1949, 44, 248.

15. Mc. Knight, R. B.: J. Amer. med Ass. 1928, 90, 1929.

16. Newsom, I. E.: J. infect. Dis. 1938, 63, 232.

17. Nickel, R. und Gisske, W.: Z. Fleisch- u. Milch- hyg. 1941, 51, 225.

18. Ochsner, A. and D'eBakey, M.: Surg. Gynec. Obstet. 1938, 66, 426.

19. Overholt, R. H.: Arch. Surg. Chicago 1931, 22, 691.

20. Overholt, R. H. and Donchess, J. C.: New England J. Med. 1935, 213, 294.

21. Reimers: Zeitschr. f. d. ges. Fleischbesch. u. Trikinensch. 1904, 1, 49. Ref. Jahresbericht 1904, 307.

22. Robinson, T. J., Jasper, D. E. and Guilbert, H. R.: J. Amer. Sc. 1951, 10, 733.

23. Rubarth, S.: Skand. Vet. Tidskr. 1942, 32, 78.

24. Rubarth, $S$. and Wollarz, E.: The VI Nord. Veterinärmötet Stockholm 1951, 30.

25. Schumann, K.: Diss. Dresden 1908.

26. Smith, H. A.: Amer. J. Vet. Res. 1944, 5, 234.

27. Spellberg, Mitchell A.: Diseases of the Liver, Grune and Stratton, New York, 1954, 186 and 188.

28. Söderlind, O.: Mh. Vet Med. 1958, 13, 737.

29. Thorek, P.: Surgery 1947, 21, 739.

30. Wyssmann, E.: Schweiz. Arch. 1912, 54, 276.

31. Yamamoto, S.: J. Jap. Soc. Vet. Sci. 1938, 17, 40. 


\section{SUMMARY}

Hepatic abscesses in cattle with rupture into the caudal vena cava are described. During the years 1934 to 1959 , a total of 56 such lesions were encoutered in the 1279 autopsies of mature cattle carried out at the Department of Pathology, Royal Veterinary College, Stockholm. As a rule, these animals had died suddenly and unexpectedly. The characteristic autopsy findings were emphysema, haemorrhages, and oedema in the lungs, haemorrhages in the respiratory passages, and subendocardial and subepicardial petechiae. Haemorrhagic oedema was often seen subcutaneously as well as inter- and intramuscularly. The pulp of the swollen spleen was hyperaemic and soft, the lymph nodes were hyperaemic, oedematous, and haemorrhagic. The blood was generally well clotted as a black-red "currant-jelly" clot. The abscess which had discharged its contents in the caudal vena cava usually lay within the liver and less commonly was situated subphrenically between the diaphragm and the liver or within the thorax or, in one occasion, retroperitoneally about the kidney. From the abscess contents were isolated Corynebacterium pyogenes animalis or streptococci or both these together, and F. necrophorus, alone or together with streptococci.

\section{ZUSAMMENFASSUNG}

Hepathogene und subphrenische Abszesse mit Einbruch in die V. cava caudalis beim Rind.

Der Verfasser berichtet über 56 in der Abteilung für Pathologie der Veterinärhochschule in Stockholm während der Jahre 1934-1959 aus einem Material von 1279 Rinderobduktionen gesammelte Leberabszessfälle mit Einbruch in die $V$. cava caudalis. Die Tiere starben in der Regel ganz plötzlich und unerwartet. Das Obduktionsbild kennzeichnete sich durch Emphysem, Blutungen und ödem in den Lungen, eine Blutungsneigung in den Respirationswegen sowie subepi- und subendokardial. Subkutan und inter- wie intramuskulär kam oft hämorrhagisches ödem vor, die geschwollene Milz hatte eine blutreiche und lose Pulpa und in den Lymphknoten waren Hyperämie, Ödem und Blutungen vorhanden. Das Blut war in der Regel gut koaguliert und schwarzrot. Der Abszess, der seinen Inhalt in die V. cava caudalis entleert hatte, sass gewöhnlich in der Leber, war aber zuweilen subphrenisch zwischen Diaphragma und Leber sowie in einigen Fällen im Thorax oder retroperitoneal an der einen Niere gelegen. Die bakteriologische Untersuchung des Abszessinhalts ergab Infektion mit Corynebacterium pyogenes animalis, Streptokokken, eine Mischung dieser beiden Keimarten sowie $F$. necrophorus oder diesen gemeinsam mit Streptokokken. 


\section{SAMMANFATTNING}

Hepatogena och subfreniska abscesser med inbrott $i$. cava caudalis hos nötkreatur.

Förf. lämnar en redogörelse för 56 fall av leverabscess med inbrott i $V$. cava caudalis hos nötkreatur insamlade å avdelningen för patologi vid Veterinärhögskolan i Stockholm under åren 1934-1959 ur ett material på 1279 nötkreatursobduktioner. Djuren ha som regel dött mycket hastigt och oväntat. Obduktionsbilden har präglats av emfysem, blödningar och ödem i lungorna, en blödningsbenägenhet i respirationsvägarna samt subepi- och subendokardialt. Subkutant samt inter- och intramuskulärt förekom ofta ett hämorrhagiskt ödem, i den svullna mjälten en blodrik och lös pulpa samt i lymfkörtlarna hyperämi, ödem och blödningar. Blodet var som regel väl koagulerat och svartrött. Den abscess, som tömt sitt innehåll i $V$. cava caudalis, satt vanligen i levern men var ibland belägen subfreniskt mellan diafragma och lever samt vid några tillfällen $i$ thorax eller retroperitonealt vid ena njuren. Den bakteriologiska undersökningen av abscessinnehållet visade infektion med Corynebacterium pyogenes animalis, streptokocker, blandning av dessa båda samt $F$. necrophorus eller denna tillsammans med streptokocker.

(Received June 20.1960). 